\title{
PREVENTIVE SELF-CARE IN THREE FREE STATE COMMUNITIES
}

C J van Zyl-Schalekamp

Since the mid 1970's the professional health scctor began to relinquish its traditional opposition to sclf-carc, duc to the realization that sclf-carc in fact may bencfit formal health care services. These changes in sentiment were duc mainly to two factors:

(a) The dramatic increasc in chronicdegenerative discases with a concomilant decrease in acute-infective conditions. This implied a shift from "curc" to "care" and a much greater extent of patient participation (Dcan 1981:673; Levin 1977:116; Pratl 1973:27; Segall \& Goldstein 1989:154; Williamson \& Danaher 1978:20).

(b) The cost crisis experienced by all formal health care systems. On the side of the consumer, costs may be curtailed by reducing both the demand and the need for professional health carc. Secmingly, the demand for care may be scaled down by increasing the financial costs to the consumer ( $\triangle$ bel-Smith 1980:26; Maynard 1986:1 164) and by developing the sclf-carc skills of patients (Levin et al. 1977:26; Williamson \& Danaher 1978:73). The need for carc may be reduced by creating "heal thicr" populations - in this sclf-carc in the form of prevention, health mainienance ind healthicr life styles may also play a rolc (Levin ct al. 1977:31; Mechanic 1975:242).

Outside the professional and policy sector, dissatisfaction with various characteristics of the professional care system focused additional attention on self-care as a potential contributor in health carc. Criticism of formal health carc centered on the following:-

* Limited effectiveness and appropriateness of formal care, especially duc to its clinical/biomedical orientation. Care furthermore tends to be fragmentary and episodic, rather than comprehensive and continuous (Dean 1986:275; Juffermans 1983:225; Katz \& Lcvin 1980:330; Levin 1976:70).

- The inadequatc or differential availability of official carc, both in geographic and socio-cconomic terms (l_cvin cl al. 1977:23; Van der Gecsi 1987:294)

- The potentially harmful side-effects associated with the professional care-giving process, c.g. unnccessary surgery,

\section{Abstract}

There has been increasing interest in self-care as a potential role-player in health care provision. Existing knowledge abour self-care however, is regarded as insufficient, and such knowledge is especially relevant when governments plan to support self-care development programmes. A survey on self-care among whites, blacks and coloureds in the Free State also focused on preventive self-care, and large differences were found between the three groups. Due to several factors, a uniform self-care development programme for all population groups in South Africa, will not be viable.

\section{Opsomming}

Daar is toenemende belangstelling in die moontlike rol wat selfsorg in gesondheidsorgvoorsiening kan speel. Bestaande kennis oor selfsorg word egter as ontoereikend beskou, terwyl sodanige kennis juis noodsaaklik is indien regerings selfsorgontwikkeling steun. In 'n opname oor selfsorg onder wittes, swartes en kleurlinge in die Vrystaat, wat deels op voorkomende selfsorg gefokus het, is groot verskille ussen die drie groepe gevind. Die lewensvatbaarheid van 'n eenvormige selfsorgontwikkelingsprogram vir alle bevolkingsgroepe van Suid-Afrika, word deur verskeie. faktore geïnhibeer.

over-prescribing of drugs, maximum intervention and the medicalization of socicty (Juffermans 1983:224; Lcvin 1977:117; Pratt 1973:23).
* Depersonalization of the patient, overspecialization and technological bias (Ficld 1980:402; Griffiths \& Bankowski 1980:61).

These negative experiences with the formal health care system contribuled to a loss of confidence in professional care and a search for alternatives. "The self-carc, self-help movements work for less arcanc, more humanc, less technical and specialized, more decentralized and accountable approaches to medical care delivery" (Katz \& Levin, 1980:329). Additionally, the appeal for more sclf-care has becn assisted by rising educational levels among the general population and the increasing availablity of health and sclf-care information (Lcvin et al. 1977:22; Pratt 1973:26; Quah 1977:23; Van Wanscelc \& Branckacrs 1982:19).

With renewed interest in self-care, efforts were made to provide relevant findings for South Africa on the extent of self-care practices. Despite sludics already published, existing knowledge of self-care is regarded still as fragmentary and unsatisfactory and particularly so in South Africa.

It is emphasized that a descriptive dale base on self-carc is required (Dean 1981:686). Such a data base is above all essential when governments have made policy decisions regarding the promotion of sclf-care. This is the case in South Africa, as evidenced by the pronouncement of the Minister of Ilealth and Population Development on 14 May 199(): "Ihe health service should be preventive and promotive and stimulate sclf-care in the community, which has to take responsibility for its own health." As part of a-broader project of the IISRC on affordable social security, a study was consequenlly undertaken during 1989 to establish the nature and extent of existing self-carc patterns in threc Frec State communitics (Van Zyl-Schalckamp 1990). (The complete rescarch report on self-care is available from the ISRC).

\section{SUBJECTS AND METHOIS}

$\wedge$ questionnaire was desi gned and administered to threc multi-phase random cluster samples of respondents: (1) 149 white households in l3locmfontein; (2) 150 black houscholds in Mangaung (the black township adjacent to 13locm(ontein); and (3) 137 coloured houscholds in Ileidedal (the coloured township adjacent to Blocmfontcin). $\wedge$ total of 45 intervicwers, mostly sludents, were recruited to 
conduct interviews in their own communities. Interviews had to be conducted with "the woman of the house". The questionnaire covercd the following aspects: (1) socio-demographic particulars of respondents (e.g. age, level of education); (2) other correlates of self-care, such as health knowledge; (3) the differential availability and accessibility of professional health care; (4) the perceived health status of the respondent and her (nuclear) family; and (5) the nature and extent of different self-care modalities, e.g. preventive care and self-medication. In addition, in-depth interviews were conducted with black and coloured community leaders in order to gain feedback on some of the survey findings. This was considered necessary as the researcher, being white herself, lacked in-depth knowledge of black and coloured communities and wished to avoid unwarranted conclusions.

\section{FINDINGS}

The different forms of prevention/health maintenance studied, were (1) the most important activities undertaken by respondents to protect their health; (2) regular physical, dental and cervical (Papanicolaou) examinations: (3) the inclusion or avoidance of certain types of food in the diet; (4) immunization and (5) exercise.

\section{Health protective activities}

In response to the question about the most important action that respondents take to protect their health, a healthy diet was emphasized by all three groups, while sufficient rest was stressed expecially by the coloured respondents as shown in Table 1.

The category healthy/clean living included responses such as the following: fresh air, warm clothes and hygiene.

Incidentally, the black group reported the highest extent of medicine use during the two weeks preceding the interview, which is

Table 1

Most Important Health Protective

Activity for whites, blacks and coloureds, in percentages

\begin{tabular}{|l|r|r|r|}
\hline & \multicolumn{1}{|c|}{$\begin{array}{c}\text { White } \\
(149)\end{array}$} & \multicolumn{1}{|c|}{$\begin{array}{c}\text { Black } \\
(150)\end{array}$} & \multicolumn{1}{|c|}{$\begin{array}{c}\text { Coloured } \\
(\mathbf{1 3 7})\end{array}$} \\
\hline $\begin{array}{l}\text { Healthy } \\
\text { diet }\end{array}$ & 53,0 & 24,7 & 32,1 \\
\hline $\begin{array}{l}\text { Healthy/ } \\
\text { clean } \\
\text { living }\end{array}$ & 12,1 & 17,4 & 10,2 \\
\hline $\begin{array}{l}\text { Consuly } \\
\text { medicate }\end{array}$ & 2,0 & 20,6 & 13,1 \\
\hline Exercise & 13,4 & 8,7 & 13,9 \\
\hline $\begin{array}{l}\text { Sufficient } \\
\text { rest }\end{array}$ & 12,8 & 8,0 & 21,9 \\
\hline Work & 2,7 & 5,3 & 4,4 \\
\hline Nothing & 4,0 & 15,3 & 4,4 \\
\hline TOTAL & 100,0 & 100,0 & 100,0 \\
\hline
\end{tabular}

confirmed by their "consult/medicate" response in this instance.

\section{Regular physical, dental and cervical (Pap) examinations}

The responses regarding routine medical, dental and cervical examinations are presented in Table 2.

Quite a big proportion of the coloured respondents reported undergoing regular phusical examinations. due to the widespread availability of clinic and school clinic facilities in the coloured residential arca. Relative to population size the coloured population is better served by clinics than blacks and this was commented on during the in-depth intervicws. Both in the black and white groups regular physical examinations were found to be associalco with perceived poor family health, and in the black group a high family income was found to be posilively associatcd with regular physical examinations.
TABLE 2

Dental Examinations and Cervical (PAP) smears for whites, blacks and coloureds, in percentages

\begin{tabular}{|c|c|c|c|}
\hline & White & Black & Coloured \\
\hline \multicolumn{4}{|c|}{ Regular Physical Examination } \\
\hline All family members & 23,5 & 15,3 & 42,3 \\
\hline Some members & 20,8 & 18,0 & 14,6 \\
\hline Uncertain & 1,3 & 5,4 & 4,4 \\
\hline \multirow{3}{*}{$\begin{array}{l}\text { No regular physical } \\
\text { examination }\end{array}$} & 54,4 & 61,3 & 38,7 \\
\hline & 100,0 & 100,0 & 100,0 \\
\hline & $(N=148)$ & $(N=149)$ & $(N=136)$ \\
\hline \multicolumn{4}{|c|}{ Regular Dental Examination } \\
\hline All family members & 67,8 & 7,3 & 32,8 \\
\hline Some members & 11,4 & 3,9 & 27,7 \\
\hline Not applicable & 3,4 & 0,0 & 2,3 \\
\hline \multirow{3}{*}{$\begin{array}{l}\text { No regular dental } \\
\text { examination }\end{array}$} & 17,4 & 88,8 & 37,2 \\
\hline & 100,0 & 100,0 & 100,0 \\
\hline & $(N=144)$ & $(N=149)$ & $(N=134)$ \\
\hline \multicolumn{4}{|l|}{ Cervical Smear } \\
\hline Somi-/annually & 67,5 & 10,4 & 46,9 \\
\hline Every 2.5 years & 12,7 & 0,0 & 3,6 \\
\hline Seldom & 13,5 & 11,4 & 10,8 \\
\hline Never & 6,3 & 8,3 & 28,8 \\
\hline \multirow[t]{3}{*}{ Ignorant } & 0,0 & 69,8 & 9,9 \\
\hline & 100,0 & 99,9 & 100,0 \\
\hline & $(N=126)^{1}$ & $(N=96)^{1}$ & $(N=111)^{1}$ \\
\hline
\end{tabular}

${ }^{1}$ Only the responses of females under 55 years of age were taken into consideration.

The biggest extent of regular dental examinations was reportcd by the white respondents. In all three groups regular dental checks were associated with high levels of education and health knowledge, as well as with high family income and the availability of medical insurance. The differential availability of medical insurance was marked by the fact that $9.5 \%$ of the white, $27 \%$ of the coloured but only $12 \%$ of the black respondents claimed to have medical insurance.

The extent of reported regular cervical (Pap) tests was distressingly low, especially among the black respondents. Two remarks regarding this are pertinent:- (1) Due to the sensitivity of the topic and cultural taboos, black women may have been unwilling to discuss this subject with young, gencrally male intervicwers; (2) During the in-depth interviews it was alleged that cervical smears arc mosily carricd out on females who visit family planning clinics and often only on those women who use IUIDs. In both the whitc and black groups, regular Pap tests were strongly associated with a high Ievel 
of education, and in the coloured group with a high family income.

\section{The inclusion or avoidance of certain types of food in the diet.}

The highest extent of food inclusion as well as food avoidance was reported by the white respondents; $75,8 \%$ of those respondents indicated that they tried to include specific foods in the diet, especially vegetables, protein and fibrous food. The most important motivation given was the perceived need for a healthy or balanced diet. Efforts at specific food inclusion occurred especially among those with higher lcvels of education and health knowledge, and with the lowest frequency among the youngest and oldest age groups. Food avoidance, especially of foods containing cholesterol, fat or oil, was reported by $43,6 \%$ of the white respondents, largely due to health concerns. Apart from high education and good health knowledge, food avoidance in this group was also associated with high perceived family morbidity.

1 percent of the black respondents reported efforts at specific food inclusion, mainly vegetables and protein, for purposes of a healthy or balanced diet. In both the black and coloured groups, food inclusion was associated with high levels of education and health knowledge, but showed a decrease with increasing age. About a third of respondents in the black group indicated avoidance of certain foods in the family dici; oily or fatty foods, owing to health

TABLE 3

Immunization against Polio, Diphtherla, Whooping Cough and

Tuberculosis for whltes, blacks and coloureds, in percentages

\begin{tabular}{|c|c|c|c|}
\hline & $\begin{array}{l}\text { White } \\
\text { (149) }\end{array}$ & $\begin{array}{l}\text { Black } \\
(150)\end{array}$ & $\begin{array}{c}\text { Coloured } \\
\text { (137) }\end{array}$ \\
\hline \multicolumn{4}{|l|}{ Pollo } \\
\hline amily & 94,0 & 37,3 & 84,7 \\
\hline $\begin{array}{l}\text { Did not } \\
\text { know }\end{array}$ & 2,7 & 15,3 & 5,1 \\
\hline \multicolumn{4}{|c|}{ Diphtheria } \\
\hline $\begin{array}{l}\text { All family } \\
\text { members }\end{array}$ & 91,3 & 21,3 & 81,8 \\
\hline $\begin{array}{l}\text { Did not } \\
\text { know }\end{array}$ & 2,7 & 25,3 & 7,3 \\
\hline \multicolumn{4}{|c|}{ Whoopling Cough } \\
\hline $\begin{array}{l}\text { All family } \\
\text { members }\end{array}$ & 88,6 & 24,0 & 80,3 \\
\hline $\begin{array}{l}\text { Did not } \\
\text { know }\end{array}$ & 4,0 & 16,0 & 8,0 \\
\hline \multicolumn{4}{|c|}{ Tuberculosle } \\
\hline $\begin{array}{l}\text { All family } \\
\text { members }\end{array}$ & 85,9 & 41,3 & 83,9 \\
\hline $\begin{array}{l}\text { Did not } \\
\text { know }\end{array}$ & 2,7 & 2,7 & 5,8 \\
\hline
\end{tabular}

considerations, and pork, duc to religious convictions were avoided. Personal distaste and allergies also were advanced as reasons for food avoidance. As in the whitc group, food avoidance in the black group was associated with high levels of education and health knowledge and perceived high family morbidity.

The coloured group presented the lowest levels of both specific food inclusion $(44,5 \%)$ and avoidance $(20,4 \%)$ and followed the same patterns as in the black group

\section{Immunizution}

Qucstions about immunization against poliomyclitis, diphthcria, whooping cough, tclanus, measles and tuberculosis produced disturbing figures for the black population. Table 3 presents the responses received regarding some components of immunisation.

The respondents in the in-depth interview attributed the low reported immunization figures in the black community to an carlicr resistance to immunization. In addition, large-scale immunization campaigns are a fairly recent phenomenon, which implies that older people often have not been reached. The high incidence of tuberculosis among blacks has probably provided for a better immunization coverage for this condition. Among the black respondents a high "do not know" response was cncountered, which is in itsclf significant. No associations were found between variables such as cducation, incomc or immunization in any of the three groups.

\section{Exercise}

The three groups differed regarding the most common types of excrcise reported as shown in Figure 1. The whites clearly can avail themselves of more varied types of exercise, while the black group performs more physical labour than do members of the other two groups.

\section{DISCUSSION}

Any effort towards self-care development must take cognisance of South Africa's population composition. Different ethnic groups often are characterized by distinclive cultural values and beliefs, which are among other things, reflected in their health and illness behaviour. The perception and definition of health and illness, disease explanations and acceptable forms of care therefore are influenced by group traditions, rcligious convictions, family organization, childrearing patterns, clc. (I.itman 1974:504; Quah 1985:353; Suchman 1964:319).

In comparison with the whites and urban coloureds in South Africa who have a bio-medical approach to heal th and disease, the black group, to a large extent, has an unique view of health, which is seen as expression of a cosmic equilibrium; scrious illness may be ascribed to an imbalance of cosmic powers (Manganyi 1974:922). Regarding discase causation, black South Africans distinguish between diseases with natural or clear causes, and diseases which can only be explained by magic (Murdock 1980:8; Pretorius 1990:104; Read 196(6:24). The particular theory of discase causation determines its treatment - by implication this includes self-care activitics
FIGURE 1

The most important type of exercise for whites, blacks and coloureds, In percentages
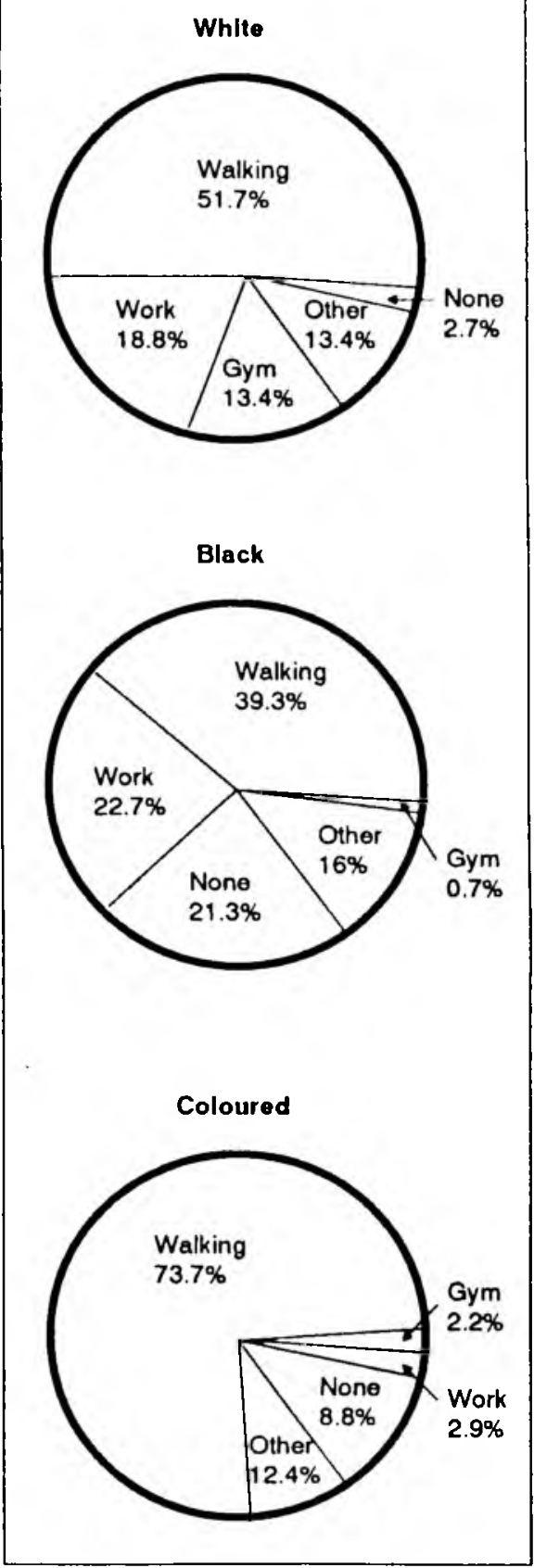

both preventive and therapeutic. The differences in the preventive self-care practices of the three groups identificd in this study obviously can not be only ascribed to cultural differences, but it will be short-sighted to neglect cultural factors in efforts to develop self-care skills.

Furthermore, a uniform sclf-carc development programme for all groups will not he viable, due to differences regarding educational, income, health knowledge and morbidity levels, morbidity patterns, and important sources of information regarding health, discase and medicines. Very important 100 , are the inequalities in the availability and acecssibility of formal health care to the different population groups. Not only the contents of self-care development programmes will have to be group-specific, but also the methods of 
education. The results of the study show that the mass media would be very effective for the black community, interpersonal sources of information in the coloured community, while medical sources and the mass media are most relevant for the white community. However, care should be taken that differential self-care development programmes do not perpetuate or even enhance current structural inequalities in health care provision.

\section{REFERENCES}

ABEL-SMITH B 1980. Economics and health policy: An overview. In Griffiths A \& Bankowski Z (eds.) 1980. Economics and Health policy. Proceedings of the 13th Round Table Conference, Geneva, Switzerland 8-9 November 1979. Geneva: Council for International Organizations of Medical Sciences and the Sandoz Institute for Health and Socio-Eoonomic Studies.

DEAN K 1981. Self-care responses to illness: A selected review. Social Science and Medicine 15a: 673:-687.

DEAN K 1986. Lay care in illness. Social Science and Medicine 22(2):275-284.

FIELD MG 1980. The health system and the polify: A contemporary American dialectic. Social Science and Medicine 14a:397-413.

GRIFFITHS A \& BANKOWSKI Z(eds.) 1980. Economics and Health Policy. Geneva: Council for International Organizations of Medical Sciences and the Sandoz Institute for Heal th and Socio-Economic Studies.

JUFFERMANS PC 1983. Medicalisering, zeltzorg en de crisis van de verzorgingstaat. Medisch Contact 38(8):224-226.

KATZ AH \& LEVIN LS 1980. Self-care is not a solipsistic trap: A reply to critics. Intemational Joumal of Health Services 10(2):329-336.
LEVIN LS 1976. Self-care: An international perspective. Social Policy Sept/Oct:70-75.

LEVIN LS 1977. Forces and issues in the revival of interest in self-care: Impetus for redirection in health. Health Education Monographs 5(2):115-120.

LEVIN LS, KATZ AH \& HOLST E 1977. Self-care lay initiatives in health. New York: Prodist.

LJTMAN TJ 1974. The family as a basic unit in health and medical care: $A$ social-behavioural overview. Social Science and Medicine 8:495 -519.

MANGANYI NC 1974. Health and disease: Some topical problems of sociocultural transition. South African Medical Journal 48(21):922-924.

MAYNARD A 1986. Public and private sector interactions: An economic perspective. Social Science and Medicine 22:1161-1166.

MECHANIC D 1975. Ideology, medical technology and health care organization in modern nations. American Journal of Public Health 65:241-247.

MURDOCK GP 1980. Theories of illness: $A$ world survey. Pittsburgh: Pittsburg University Press.

NUYENS Y 1982. Sociologie en gezondheidzorg. Vol. 2 AntwerpenDeventer: Van Loghum Slaterus.

PRATT L 1973. The significance of the family in medication. Journal of Comparative Family Studies 4:13-35.

PRETORIUS E 1990. Die rol en benutting van tradisionele helers in ' $n$ swart woongebied by Bloemfontein. Unpublished D Phil. dissertation. Bloemfontein: University of the Orange Free State.
QUAH SR 1977. Self-medication: A neglected dimension of health behaviour. Sociological Symposium 19:20-36.

QUAH SR 1985. The health belief model and preventive health behaviour in Singapore. Social Science and Medicine 21:351-363.

READ M 1966. Culture, health and disease. London: Tavistock.

SEGALLA \& GOLDSTEIN J 1989. Exploring the correlates of self-provided health care behaviour. Social Science and Medicine 29(2):153-161.

SUCHMAN EA 1964. Sociomedical variations among ethnic groups. American Journal of Sociology 70:319-331.

VAN DER GEEST S 1987. Self-care and the informal sale of drugs in South Cameroon. Social Science and Medicine 25(3):293-305.

VAN WANSEELE C \& BRANCKAERTS J 1982. Zclfhulp als maatschappelid fenomeen. In Nuyens Y. Sociologie gezontheidzorg 2:11-26.

VAN ZYL-SCHALEKAMPCJ 1990. Selfsorg in siekte en gesondheid: ' Medies-sosiologiese studie in drie gemeenskappe. Unpublished D Phil dissertation. Bloemfontein: University of the Orange Free Statc.

WILLJAMSON J D \& DANAHER K 1978 Self-care in health. London: Croom Helm.

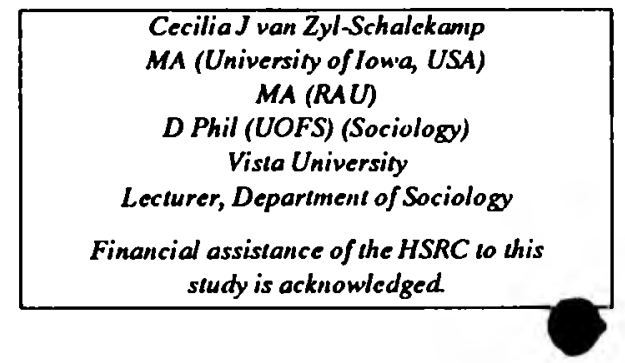

